\title{
Produção de Sentido Subjetivo: As Singularidades dos Alunos no Processo de Aprender
}

Subjective sense production: The singularities of students in the learning process
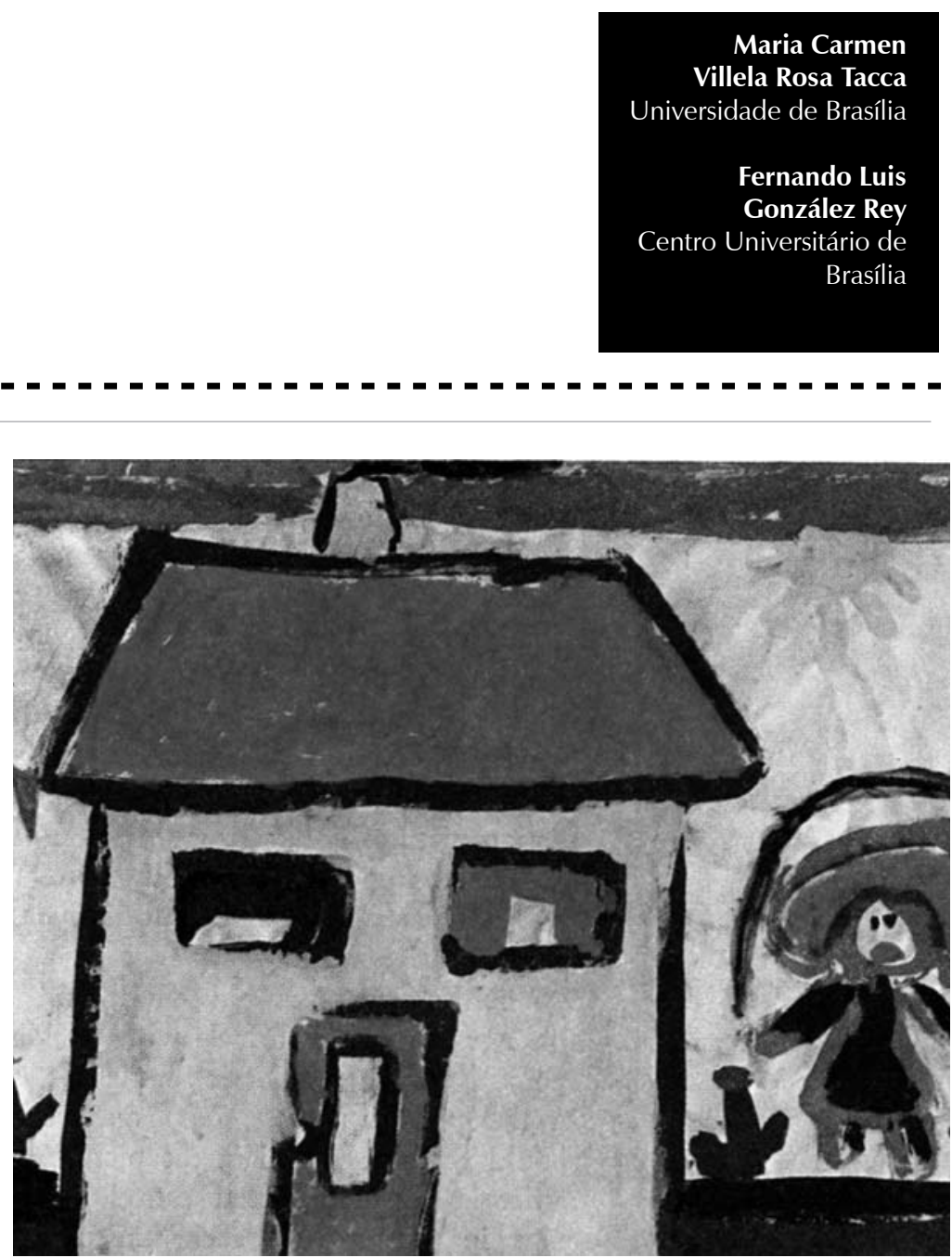
Resumo: Neste artigo, procuramos identificar como o sentido subjetivo se manifesta e está na base dos processos de aprendizagem de cada aluno, revelando a sua singularidade enquanto pessoa. Para essa compreensão, foi realizada uma pesquisa com base nas categorias de subjetividade e sentido subjetivo de González Rey. Nela esteve envolvida uma professora e sua turma de $4^{a}$ série do ensino fundamental. $\mathrm{Na}$ análise dos dados, foi possível compreender as formas como os alunos utilizavam as informações que constavam das atividades na conjuntura de seus recursos pessoais, no que emergiam diferentes sentidos subjetivos para construir caminhos de aprendizagem. Conclui-se que a aprendizagem se encontra envolvida com a produção de sentidos subjetivos procedentes dos diferentes espaços e situações de vida do aluno. Assim, considerar essa dimensão permitiria ações diferenciadas orientadas ao apoio à criança no avanço contínuo de sua escolaridade.

Palavras-chave: Sentido subjetivo. Crianças em idade escolar. Aprendizagem. Subjetividade.

\begin{abstract}
In this article we seek to identify how the subjective sense manifests itself and constitutes a starting point for each student learning process, reveling his/her singularity as a person. To better understand this idea, the research was carried out based on Gonzalez Rey's categories of subjectivity and subjective sense. In this research, an elementary school group of 4th graders and their teacher were involved. Data revealed how students used the information included in the activities together with personal resources, creating subjective sense in order to build paths to learning. In conclusion, we found that the learning process is related to the creation of subjective senses that arise from several spaces and situations in a student's life. Therefore, consider this dimension would allow targeted actions towards supporting the continued classroom progress of the student.
\end{abstract}

Keywords: Subjective sense. School age children. Learning. Subjectivity.

\title{
Produção de sentido subjetivo: as singularidades dos alunos no processo de aprender
}

Aprender é uma atividade que precisamos desempenhar, pois sem ela não conseguiremos sobreviver. Ao chegar ao mundo, essa necessidade da vida humana começa a se impor sem que haja um ponto de chegada. As pessoas se precipitam para experiências e experimentações diversas durante a vida, e todas elas resultam em algo aprendido. Isso nos caracteriza enquanto seres humanos de forma bastante diferenciada em relação aos animais. Se aprendemos no nosso dia a dia, nós o fazemos sempre nas relações sociais, em diferentes grupos sociais e com propostas e objetivos diferentes. No entanto, além de aprender para sobreviver, ou melhor, para viver, devemos também aprender para ser, pois essa atividade nos constitui enquanto pessoas, nas nossas trocas constantes, ou seja, no âmago dos processos de socialização.

No entanto, o conhecer na vida social ganhou uma importância e necessidade que levou a aprendizagem além do âmbito das relações informais. $\mathrm{Na}$ história da organização social, na medida em que a sociedade produziu conhecimento e novas descobertas foram realizadas pelas ciências, apareceram diferentes formas de organização, significação e utilização desse conhecimento. Isso gerou a necessidade de 
A afirmação da idéia de que a escola é um bem em si mesma, que tem o papel de democratizar 0 saber, que pode fazer a mudança social, fez com que ela precisasse ser eficiente. acompanhar tanto as descobertas como as mudanças delas decorrentes e de participar de novas formas que se impuseram na organização da vida social.

Assim, entre outras, uma organização social apareceu nas sociedades na Idade Média inicialmente com o objetivo de agregar pessoas que queriam aprender algumas habilidades, obter informações ou discutir temas contemporâneos (Ariès, 1978), e dela surgiu uma organização maior, a escola, que, no seu processo de instituição, foi, ao longo do tempo, passando por mudanças ao atender à necessidade de agregar e socializar um conhecimento incessantemente produzido. De uma forma muito pouco burocrática na sua organização inicial (Ariès, 1978), foi crescendo em formalização. Depois, no entendimento de que o acesso ao conhecimento também criava acesso a bens materiais e fazia a ascensão social, foi se consolidando como um espaço gerador de privilégios, pois ter acesso ao conhecimento também poderia gerar diferentes oportunidades sociais.

No entanto, na crítica a essa perspectiva enviesada e no entendimento de que os privilégios precisariam ser democratizados, começam os movimentos para a sua popularização, mas ainda como um bem a ser conquistado, um direito a ser obtido. Assim, através dos tempos, a escola ganha espaço, prestígio, se fortalece, mas também assume uma incumbência desafiadora, pois deverá concretizar o ideal de democratização do conhecimento. Essa incumbência assumida implicou uma armadilha.

Portanto, historicamente, de uma escola que se destinava a ensinar aquilo que se quisesse e para quem quisesse, passa-se pelos diversos estágios de uma escola que cada vez mais precisa atender muitos, ou atender todos, mas que, de certa forma, pelas opções que fez, se projetou para atender poucos ou um grupo específico, com um objetivo específico. Isso aconteceu porque ela se estabeleceu com um modelo do tipo tamanho único, ou seja, em um único formato que deve se ajustar a todos indistintamente, o que lhe dá um perfil com forte tendência para a padronização, formalização e hierarquização. A confiança de que esse é o modelo necessário carrega a idéia de que todos são iguais e devem aprender as mesmas coisas, ao mesmo tempo e da mesma forma.

Na busca e consolidação desse projeto, na sociedade atual, a escola é uma instituição das mais fortalecidas, e cumpre a função de ensinar e educar. Nela qualquer criança deve ter lugar garantido e não se admite que não o ocupe. Isso permite concluir que, de uma escola a ser freqüentada pelo desejo de saber, chega-se a uma escola na qual a aprendizagem aparece como obrigatoriedade.

A afirmação da idéia de que a escola é um bem em si mesma, que tem o papel de democratizar o saber, que pode fazer a mudança social, fez com que ela precisasse ser eficiente. Para isso, assimilou em sua proposição a fragmentação do conhecimento como modelo formal (Morin, 1999), assumindo as disciplinas ou matérias escolares como espaço de organização do conhecimento produzidosocialmente. Assim, linguagem, Matemática, História, Geografia e ciências, entre muitos outros, compõem a rede de conhecimentos a serem transmitidos na escola, que caracteriza o conhecimento escolar e que encaminha para a idéia de uma correspondente aprendizagem escolar. O conhecimento, transmitido em um formato didático, reduzido e simplificado, orientado pelos conceitos científicos, é o que caracteriza esse conhecimento escolar ou aquilo que deve ser aprendido na escola (Tunes, Tacca, \& Mitjáns Martinez, 2006). 
Esse formato apóia-se na criação de unidades especificadas para facilitar a transmissão, o que veio a caracterizar a escola muito mais como reprodutora de um conhecimento já produzido, e distanciou-a da possibilidade de constituir-se em produtora de conhecimento.

Em decorrência, os alunos, ao freqüentarem a escola, são orientados a utilizar, dentre todas as suas funções, quase que exclusivamente as funções cognitivas e intelectuais, em especial a memória, com base nas habilidades de atenção e concentração, o que faz com que a função reflexiva produtiva e personalizada da aprendizagem fique em segundo plano, por não participar do foco das atividades propostas (González Rey, 2006). Sem dúvida, esses outros aspectos estarão presentes nas atividades, pois o sujeito não se fragmenta, mas comporta-se como se se constituísse em um sistema, mas isso fica submerso, despercebido e desvalorizado, e, assim, não é acompanhado e incentivado pelos professores. Portanto, baseando-se naquilo que a escola propõe, a utilização de funções e habilidades mais mecânicas é o que possibilitará ao aluno ser bem sucedido.

Acontece que, embora não seja uma tarefa muito difícil selecionar um corpo de conhecimentos e até propor as disciplinas e unidades com as quais se pode elaborar um currículo escolar a ser prescrito para todos, em todas as escolas, o que poderíamos representar como currículo "tamanho único", de alguma forma e por várias interferências, teria muita probabilidade de não levar à aprendizagem em um formato uniforme, como previsto. Essa previsão aparece simplesmente porque as pessoas não se comportam de forma homogênea, mas constituem-se no âmago da diversidade de seus processos psicológicos, que incluem aspectos cognitivos, emocionais e habilidades bem como todo um cenário e contexto que oportunizam diferentes sugestões e formas de aprender.
O desafio da escola sempre será o de transitar entre a igualdade e a diferença, entre aquilo que precisa e deve ser igual para todos e entre aquilo que só pode ser visto sob o prisma da diversidade. Se existe a necessidade de se objetivar um conteúdo originário da produção de conhecimento da humanidade a que todos devem ter acesso, em contrapartida, a escola não poderá e não deverá propor isso em modelos únicos. Ao se pensar a democratização do saber, foi formalizado um saber padrão para pessoas padronizadas, o que só poderia levar ao sucesso de poucos, ou seja, daqueles para os quais o padrão melhor se adapta. A escola então comete, possivelmente, entre outros, o que identificamos aqui como cinco equívocos: 1) fragmentar o conhecimento; 2) padronizar o conhecimento; 3) padronizar as pessoas; 4) considerar a aprendizagem apenas em sua dimensão reprodutiva, sem assumir a possibilidade de sua produção, e 5) evitar considerar a aprendizagem como função do sujeito, no âmago da configuração subjetiva e da produção de sentido subjetivo. Será sobre esses aspectos, principalmente o último, que incidirão as argumentações que teceremos neste artigo, tendo em vista situar e refletir sobre as possibilidades de aprendizagem na escola.

\section{A realidade da aprendizagem escolar}

$\mathrm{Na}$ fragmentação, padronização e mecanização acima identificadas, fica caracterizado apenas um conhecimento estanque, pois dele são retirados a sua dinâmica, o seu fluxo constante de mudanças, as suas interposições e interdependências. Como diz Morin (1999), o retalhamento da disciplina (no ensino) torna impossível apreender o que é "tecido junto", o que é complexo, e é a complexidade que incita a curiosidade, pois aí está o mistério. Ao criar unidades isoladas, apresentá-las de modo isolado e simplificá-las, retira- 
se a dinâmica e o movimento de que é composta a realidade, extraindo também os desafios e a curiosidade para conhecêla. O conhecimento escolar torna-se, assim, uma listagem de conteúdos e conceitos a serem transmitidos e assimilados, no que não são alcançados os seus significados e a sua lógica. A repetição é equivocadamente vista como aprendizagem, uma vez que é nela que se apóiam as avaliações. Não se pode estranhar a apatia, a falta de interesse e de motivação, que constituem a principal reclamação de muitos professores. A escola só trabalha com o conhecimento pronto, e isso parece não impressionar mais os alunos, principalmente porque, fora da escola, a dinâmica da vida social não pára, os desafios são constantes, a ameaça está presente, e a necessidade de viver empurra para a criatividade. Diante disso, a escola recua, levanta seus muros, aparta-se dessa realidade e não traz desafios ao aluno para o uso das suas habilidades e diferentes funções para que produza, seja atuante, invente e seja inovador. Dentro da escola, hoje, os alunos vivem uma realidade apartada da vida real. O que precisa ser modernizado na escola não são as suas condições físicas, seus materiais ou o equipamento. Mais do que isso, ela precisa ser repensada enquanto modelo (Tunes \& Bartholo, 2006), pois não há dúvida de que informação o aluno pode receber, de forma fácil e a qualquer momento, mas operar, questionar, criar a partir dessa informação, não têm recebido o necessário incentivo dentro da escola. Dessa forma, a realidade da aprendizagem escolar precisa ser questionada e revista.

Temos um corpo de conhecimentos que, da forma como se realiza, deve ser repassado pelo professor e assimilado pelo aluno. Pelo menos é isso que vem retratado nos planos de curso, de aula, nos livros didáticos, nas atividades desenvolvidas nas salas de aula e na postura de professores e alunos.

Se, para professores, a atividade de aprender pode ser identificada pelas funções de adquirir, assimilar, incorporar, captar, absorver, internalizar1, do lado do aluno, parece que essa atividade não vai muito além, pois, na medida das propostas que a eles são lançadas, vão assumir a atividade de assimilação, absorção, etc., e chegarão a se convencer de que é esse o seu papel. Parece que eles também não imaginam que o aprender possa ser algo diferente, para ser realizado de forma diferente em uma escola organizada também de forma diferente. Chamou bastante nossa atenção a produção que apareceu em pesquisa realizada em escola da rede pública de ensino de São Paulo, quando se pediu aos alunos de $7 \underline{\text { a }}$ série que escrevessem um texto cujo tema era: $\mathrm{O}$ que eu quero da escola. Pensamos que os alunos fossem reinventar a escola, introduzir mudanças na sua organização, propondo que o aprender pudesse acontecer por meios que não fossem os comuns, ou seja, professor, aluno e quadro-negro, ou que fossem pedir situações em que fossem mais ativos e que houvesse uma outra proposta em relação ao conteúdo a ser aprendido, por exemplo.

Nossa surpresa foi grande ao nos depararmos com redações nas quais a maior parte dos alunos reivindicava melhorias nas condições físicas da escola, em formulações como esta: "Eu quero uma escola limpa, com banheiros limpos, com papel higiênico, espelho e sabonete, salas de aula com carteiras novas e limpas", ou então: "Eu quero uma escola mais divertida, com professores mais legais, brincalhões, e que os intervalos sejam mais prolongados". Nesses e noutros registros, evidencia-se que, para os alunos, uma escola deve ser confortável e menos enfadonha, e que aprender não parece ser a prioridade nas reivindicações. Assim, mesmo porque seria injusto pedir a eles críticas mais assertivas, parece que não será da parte dos alunos que poderá aparecer a maior pressão de reivindicações para que a escola proponha um novo modelo em sua organização. É 
bem verdade que eles acabam dizendo isso e muito mais de outra forma, como, por exemplo, pelo comportamento alheio e descompromissado com o qual não deixam claro o que querem, mas deixam evidências de que estão procurando outros desafios, outros assuntos e em outros lugares. Foi isso que ficou bem retratado no trabalho de pesquisa acima mencionado, quando foi analisado o caso de um aluno que tinha uma grande motivação para o conhecimento, mas de assuntos inusitados (esoterismo, magia, por exemplo), e não se interessava pelos conteúdos das disciplinas do currículo escolar.

Percebe-se que, mesmo com uma resistência simbólica, inevitavelmente, os alunos vão assumindo o papel que Ihes é reservado no modelo escolar, ou seja, acabam tornando-se assimiladores, repetidores, memorizadores, aplicadores de fórmulas e técnicas de multiplicar e dividir. E, como dissemos, na medida da grande diversidade e singularidade da sala de aula, a aprendizagem vai chegando onde dá, o que fica registrado em uma nota; esta é, sem dúvida, o termômetro que, na comunidade escolar, identifica o valor de cada um.

Consideramos ser muito importante fazer esta análise contextualizadora, que identifica uma conjuntura, na medida em que ela nos leva a colocar em discussão os constantes fracassos nas escolas. Sugerimos que professores e alunos estão presos em armadilhas criadas por um modelo de escola, e que cada um, a seu modo, procura cumprir o seu papel, mas que, no percurso, estranham-se, entram em conflitos e frustram-se; os professores, porque não conseguem motivar seus alunos a ponto de conseguir deles a dedicação que seria necessária, e os alunos, de fato, desmotivados, e, muitas vezes, perdidos, buscam garantir uma aprovação que lhes trará a continuidade da escolarização, entendendo ser isso o que lhes garantirá um futuro, mesmo que essa idéia ainda não tenha contornos claros para eles.

Os alunos, quanto mais novos em idade, mais confiança e disposição irão ter para acompanhar os pais e professores na argumentação da necessidade de dedicação aos estudos. No entanto, essa crença começa a esmorecer quando, justamente pela imposição do modelo acima exposto, aparecem os desacertos, os contrastes, que não são entendidos e acompanhados pela escola e pelos professores na perspectiva da eclosão da diversidade. Ao contrário, o desacertotenderáaserincluídona perspectiva do desvio, no que ficam constatadas as faltas ou dificuldades dos alunos. (Tacca, 1999, 2004, 2006). Será assim, às vezes até muito cedo, que muitos alunos começarão a viver um processo de exclusão, e, possivelmente, terão de conviver com seu fracasso caso não se ajustem ao modelo padrão proposto pela escola. Possivelmente, esses alunos até então viveram em casa ou na rua, e não lhes havia sido identificada nenhuma falta ou dificuldade na convivência diária, o que traz a desconfiança de que algo está equivocado nas relações que estão sendo estabelecidas entre eles e a escola (Patto, 1990).

Acontece que, na expectativa do início de sua trajetória escolar, o aluno carrega para a escola não só a cultura do seu grupo, que estará imersa em algo bastante profundo, a sua singularidade. Será com muitos aspectos exclusivos próprios que ele se projetará no processo da aprendizagem escolar, perfazendo essa trajetória e continuando a sua constituição enquanto pessoa nas novas e importantes experiências em um espaço social específico. Serão, sem dúvida, muitas as experiências que o marcarão e que constituirão a sua subjetividade. No entanto, pela experiência em pesquisa e em atuação nas escolas, podemos afirmar que os aspectos subjetivos dos alunos, sua 
O aluno, que precisaria ser investigado em suas possibilidades, que seriam os indicadores que ajudariam a saber o que e como trabalhar com ele, fica perdido no coletivo da turma, porque o professor entende que é bastante complicado dar atenção individualizada dentro da conjuntura de muitos alunos na sala de aula. emotividade e os sentidos que produzem no âmbito das situações de aprendizagem não são percebidos e não alcançam a preocupação dos professores na relação diária vivida em sala de aula.

Temos nos convencido de que um importante alerta sobre o peso desses aspectos na aprendizagem escolar pode ser trazido a partir dos estudos e pesquisas que se abrem para a consideração e a compreensão da subjetividade humana. A teoria da subjetividade, de González Rey (1997, 2003, 2004, 2006), permite avançar nessa reflexão, e nela estão propostas categorias que ajudam na compreensão da pessoa em sua singularidade, no contexto das múltiplas experiências nos diferentes espaços de sua vida social. Isso nos permite adentrar de forma simultânea nos alunos, em seus contextos e em suas histórias, criando condições para que se realize um trabalho pedagógico que signifique avanços no desenvolvimento. Com base nessas possibilidades é que nos colocamos no debate e na reflexão das seguintes questões: como o professor percebe o aluno que está na sua sala de aula? Como ele acha que o aluno realiza a sua aprendizagem? Como ele entende o trabalho a ser desenvolvido com o aluno? Quando ele propõe atividades, qual o seu foco? Como ele identifica a necessidade pedagógica do aluno? Que recursos e estratégias ele reúne para trabalhar com esse aluno e como percebe que ele aprendeu?

$\mathrm{Na}$ linha de pesquisa sobre aprendizagem, cotidiano escolar e subjetividade que temos procurado desenvolver e na qual também estão incluídos trabalhos realizados por nossos alunos em escolas públicas e privadas (Campos, 2005; Cardinalli, 2006; Gomes, 2005; Pinheiro, 2004, entre outros), pudemos identificar que os professores ainda vêem seus alunos baseados em crenças de que eles são sujeitos com características fixas, cuja hereditariedade e meio social se alternam como determinantes das realizações escolares. Eles também são considerados possuidores de uma escolarização deficitária, e, por esse motivo, faltam-lhes os prérequisitos para a continuidade bem sucedida da aprendizagem, que ganha significado ao ser relacionada com a capacidade de reproduzir e aplicar o conhecimento transmitido. Por isso, podemos afirmar que o foco do trabalho do professor, mesmo que ele entenda, discurse ou procure coordenar algo diferente, ainda está no conteúdo. O aluno, que precisaria ser investigado em suas possibilidades, que seriam os indicadores que ajudariam a saber o que e como trabalhar com ele, fica perdido no coletivo da turma, porque o professor entende que é bastante complicado dar atenção individualizada dentro da conjuntura de muitos alunos na sala de aula. Ele ainda desenvolve um trabalho pedagógico baseado em um planejamento cuja base de proposições está em atividades e métodos exteriores ao aluno, pois ligam-se às exigências de cunho burocrático, exigências que expressam as orientações do sistema tanto em relação aos objetivos e às alternativas de conteúdo como em relação às formas de avaliação. Assim, o professor sempre se encontrará distanciado das motivações e necessidades pedagógicas do aluno e não conseguirá apreendê-lo, alcançá-lo em seus processos de significação nas muitas proposições pedagógicas que faz. Em conseqüência, as estratégias e recursos que seleciona ficam exteriores aos alunos, já que se ligam às atividades, apenas (Tacca, 2006b).

Em uma discussão com professores de séries iniciais, usando questões já mencionadas anteriormente como base, tínhamos como objetivo argumentar que a atenção do professor nos processos subjetivos e na produção de sentidos dos alunos seria a possibilidade para a investigação de suas necessidades e a identificação das estratégias a serem empregadas na direção 
da aprendizagem de cada um deles. $\mathrm{Na}$ exploração de idéias no início da discussão, não foi difícil constatar, tal como é recorrente, que as percepções dos professores sobre a aprendizagem estavam muito sustentadas em indicadores externos ao aluno, que não the possibilitariam apreendê-lo em seus aspectos motivacionais, em suas necessidades, possibilidades e significações. Por exemplo, a atitude de atenção que significava acompanhar o professor, ou ainda fazer todas as tarefas, ter o registro organizado no caderno, a boa letra e o bom comportamento eram as referências que os professores diziam ter para a constatação daquilo que o aluno aprendeu. Não apareceu a idéia de que o diálogo pudesse ser elemento para identificar o pensamento do aluno e a manifestação dos seus processos de significação, constituindo-se em recurso para orientar o trabalho do professor.

Assim, entender a aprendizagem escolar como marcada pela subjetividade e como produção de sentido do aluno não tem sido um aspecto muito presente no espaço de convivência de professores e alunos, e também não tem sido uma vertente muito explorada na pesquisa educacional. No entanto, tal como procedemos, pensamos que esse seria um aspecto essencial a ser discutido com os professores nas escolas, para que eles pudessem ser alertados sobre o impacto que suas percepções e crenças têm sobre os processos de aprendizagem dos alunos. Esse alerta seria muito significativo, principalmente no trabalho junto às séries iniciais, nas quais a convivência diária com um só professor faz com que repousem na sua atuação e nas formas com que organiza as relações na sala de aula muitas das possibilidades de aprendizagem e desenvolvimento dos alunos. Ser compreendido na sua singularidade possivelmente livraria muitos desses alunos de rótulos estereotipados procedentes da desconsideração da forma diversa que eles têm de compreender e de se posicionar frente ao conhecimento.

\section{Subjetividade e aprendizagem: explorando conceitos}

Essa forma diversa de ver o espaço da aprendizagem imbricada na singularidade nos remete às categorias de configuração subjetiva, subjetividade social e individual e produção de sentido subjetivo, desenvolvidas nos estudos da subjetividade humana (González Rey, 1997, 2000, 2002, 2003, 2004, 2006) e que precisam ser explicitadas de forma a esclarecer a sua abrangência. Quando González Rey (2006) trata da aprendizagem como função do sujeito, propõe:

\footnotetext{
Recuperar o sujeito que aprende implica integrar a subjetividade como aspecto importante desse processo, pois o sujeito aprende como sistema, e não só como intelecto. O sentido subjetivo, na forma como temos desenvolvido essa categoria, representa um sistema simbólico-emocional em constante desenvolvimento, no qual cada um desses aspectos se evoca de forma recíproca, sem que um seja a causa do outro, provocando constantes e imprevisíveis desdobramentos que levam a novas configurações de sentido subjetivo. (pp. 33-34)
}

Fica compreendida, assim, a aprendizagem na interface e na interdependência de aspectos cognitivos/intelectuais, que irá compor um sistema dinâmico e complexo com os aspectos afetivos. Para isso, um se torna condição do outro, e não causa, e formam uma unidade sistêmica. Essa aprendizagem, então, só pode ser definida e explorada pelo próprio sujeito, que define os tipos de entrelaçamentos que serão feitos com aprendizagens anteriores, o que comporá uma complexa rede, pois não se constituirá apenas da dimensão cognitiva. Os lugares, o trânsito e o movimento dessa estruturação ganham significados e sentidos ao longo de todas as experiências 
de aprendizagem, e acompanhar toda essa movimentação ou investigá-la é uma possibilidade para o professor, uma investigação que significa procurar acessar a produção de sentido subjetivo gerada nas situações desencadeadas na sala de aula.

Nos diferentes espaços e momentos da vida social, e, entre eles, no processo de aprender, o sujeito funciona com o complexo sistema de sua personalidade, que é processual, para o que González Rey (1996) propõe o enfoque configuracional supondo que esse conceito permita entender a personalidade como sistema em desenvolvimento e como geradora e organizadora de elementos diversos e essenciais para o funcionamento do sujeito. O sujeito, assim, ao enfrentar o mundo vivido, o faz na dinâmica de uma configuração subjetiva, na qual aparece o mundo pelo qual ele se orienta. Esse mundo aparece integrado em sua dimensão simbólico-emocional como resultado da multiplicidade de desdobramentos e como conseqüência da ação social do sujeito. Portanto, a subjetividade é assumida como um "complexo sistema de formações e subsistemas psicológicos, estreitamente relacionados entre si, no que seus conteúdos e sua expressão funcional se manifestam em múltiplas e diferentes formas, tendo sentidos psicológicos diferentes" (p.85). Outra característica marcante da subjetividadeéseu caráter histórico, que abrange a história das diferentes relações do sujeito nos contextos da vida cotidiana, que é essencialmente cultural, pois que é marcada pelos sistemas de valores e construções simbólicas atuais dos grupos de referência, o que a identifica como uma intricada rede. Nessa rede, estão integrados elementos individualizados no trânsito de contínuas e mutáveis condições sociais, culturais e históricas.

Dessa forma, as teorizações do autor encaminham-se para o entendimento da subjetividade individual e social. Se a subjetividade individual é marcada pela expressão de um sujeito concreto que está envolvido em uma organização que integra o seu funcionamento psicológico, isso acontece na extensão e amplitude da subjetividade social que é marcada pelas configurações subjetivas das pessoas e grupos que se articulam nos diferentes espaços, momentos e níveis da vida social. Assim, a subjetividade social é também um sistema dinâmico e processual no qual o sujeito transita, constituindo-o, mas é parte integrante dele, na simultaneidade das implicações que esse próprio sistema social tem para ele mesmo, como um sujeito concreto, entre outros. Esse sistema, portanto, está carregado de sentidos subjetivos que se configuram em espaços mais abrangentes ou macrossociais, grupais e institucionais, e que se articulam fazendo com que os sujeitos não os tenham como determinantes, mas que funcionem ou se constituam na contínua integração com eles. (González Rey, 1997). O autor define:

A relação entre subjetividadesocial eindividual
é bem mais complexa e contraditória, por
meio da qual o comportamento do indivíduo
se expressa com diversas contradições entre
suas necessidades individuais e sociais, nas
quais deve atribuir sentido para manter seu
desenvolvimento pessoal no meio de sua
expressão social. Entre o social e o individual,
não há uma relação linear nem homogênea.
( p. 132)

Assim, para o autor, o sistema de relações de cada sujeito, que se apresenta com um caráter vivo, multidimensionado e até contraditório, é mediador e constituidor das configurações subjetivas que ele assume diante de cada situação social. O elo social e individual se ata nos sentidos psicológicos produzidos nos distintos momentos e contextos da sua vida social: "o sentido que cada momento tem para o sujeito individual é um elemento dinamizador, permanente, dos distintos sujeitos sociais em um momento histórico concreto" (Gonzalez Rey, 1996, p. 104). $\mathrm{Na}$ história de relações estabelecidas, o 
passado assume um valor que se projeta nas expressões presentes e futuras do sujeito, e, assim, passado e futuro são

momentos simultâneos de uma configuração atual da subjetividade, em que ambos constituem uma expressão da história social individual, convertida em personalidade humana, a partir da qual essa história adquire as características funcionais e reguladoras próprias do nível psicológico que não expressam nenhum tipo de relação isomórfica com eventos externos. (p. 105)

Isso significa que o autor propõe uma dinâmica complexa nas relações entre o sujeito e os eventos do meio social. A opção ontológica está definida na dialética e na recursividade do social-individual, internoexterno, aparecendo um sujeito consciente e ativo que faz opções e que se encontra implicado em rupturas, contradições e ações criativas, ou seja, "o sujeito, por sua própria condição, representa momento de permanente integração intrapsíquicainterativa, e é uma dimensão existencial de sua própria subjetividade, constituída na história de sua vida social" (Gonzalez Rey, 1997, p. 104).

Com essas afirmações, o autor se volta para a discussão da psique humana e afasta-se das formulações deterministas, por exemplo, de um inconsciente ou de uma energia pulsional de base, assumindo o trânsito constante do consciente e inconsciente, no qual não se aprisiona o sujeito em uma categoria interpretativa a priori.

A teoria da subjetividade proposta por González Rey (1996, 1997, 2000, 2003, 2004) como apoio e referencial de pesquisa traz a perspectiva de um entendimento processual do sujeito, para o que são buscados indicadores de sua configuração nas situações em que se torna importante investigar o seu funcionamento psicológico, como no caso dos processos de aprendizagem. A perspectiva interpretativa permiteadentraracompreensão dos sentidos subjetivos e significados que vão sendo construídos, voltando-se para o encontro e o confronto de indicadores, com a preocupação da apreensão do sujeito nas diferentes configurações de sua multiplicidade constitutiva, nas formas que alcança o seu funcionamento psicológico e a partir dos sentidos subjetivos que vão aparecendo e integrando o momento interpretativo. Nesse entendimento, o objetivo não é analisar a ação do sujeito dentro de um conceito explicativo que integre uma teoria, tendo em vista evidenciar o surgimento de posturas típicas, o que permitiria alcançar a mesma interpretação para pessoas diferentes. O que está proposto na teoria da subjetividade são canais interpretativos, que não ambicionam enquadrar o sujeito em uma categoria teórica explicativa, mas apreender a sua singularidade e gerar um modelo de inteligibilidade que permita definir, através dela, os elementos relevantes para o problema estudado. A subjetividade é o alvo interpretativo, e o pesquisador se dispõe a compreender a realidade subjetiva que tem diante de si, na intensa tarefa de articular os sentidos que aparecem produzidos.

Pensamos que essa perspectiva teórica, ou seja, a compreensão da subjetividade humana no funcionamento psicológico do aluno na aprendizagem, a partir da sua produção de sentido subjetivo, pode estar ao alcance do professor em sala de aula. Para isso, parece-nos claro que ele não precisará estudar conceitos teóricos, mas criar situações e espaços em que, no uso intensivo do diálogo, nas propostas de perguntas e respostas mútuas, seja possível identificar nos alunos os sentidos subjetivos que estão sendo produzidos na rede intrincada dos aspectos individuais e socais. Nessa estratégia, ele investigará o processo de aprendizagem e o percurso do pensamento para descobrir ligações e rupturas e identificar o fio constitutivo do processo de aprender, que nunca será apenas um processo cognitivo, pois a emocionalidade cria com ele uma 
unidade indivisível (González Rey, 2003; Vygotski, 1935/1997). Essa emocionalidade aparece ligada a experiências e vivências que esclarecem os aspectos que devem constituir as situações pedagógicas, cujo objetivo seja o avanço na aprendizagem.

Se a pergunta que aparece a partir dessa proposta é se ela pode ser concretizada na sala de aula, partimos para a próxima etapa deste trabalho, ou seja, apresentar os resultados de pesquisa na qual investigamos os sentidos subjetivos dos alunos no âmago de processos de aprendizagem e a forma como uma professora os utiliza na sua ação pedagógica.

\section{As singularidades dos alunos e sua expressão no processo de aprender - um estudo empírico}

No âmbito da posição teórica que coloca a aprendizagem como uma função do sujeito e assumindo a ligação entre subjetividade e aprendizagem tal como argumentamos até aqui, tivemos o interesse de investigar aspectos da subjetividade e da produção de sentido subjetivo de alunos em turmas regulares do ensino fundamental, mas que estariam enfrentando dificuldades nesse processo. Fizeram parte de um projeto maior de pesquisas escolas da região urbana e central da capital paulista, e este artigo está centrado em uma delas, que atende alunos de 1ㅁa a $4 \underline{a}$ série. Essa escola atende crianças da classe popular, filhos de pessoas que trabalham nas imediações, mas que moram em bairros mais afastados. Ela funciona em dois turnos, manhã e tarde, em cinco horas diárias cada um. Todas as turmas são regulares. As instalações físicas e os equipamentos são satisfatórios, embora não agregue nenhuma atividade ou instrumentalização que lhe dê um diferencial marcante. Ela possui boas condições de limpeza e equipamentos complementares, como televisão, vídeo, DVD, instalados em uma biblioteca com uso regular pelas turmas. A área externa é ampla, com quadra para esportes, árvores, jardins, horta e um pátio coberto. A sua participação na pesquisa se deu de forma aleatória, pois, a partir de uma exploração das escolas da região, no final do segundo semestre de 2005, foi feita visita e apresentação dos objetivos à coordenação pedagógica, que se mostrou receptiva e nos abriu a possibilidade de realização da pesquisa. No entanto, houve a consideração de que seria mais oportuno iniciar as atividades no ano letivo seguinte, o que foi acatado.

Assim, a pesquisa na escola aconteceu no primeiro semestre de 2006, desde o início de suas atividades até sua finalização. Nos primeiros contatos com a coordenação pedagógica da escola, no início do semestre, procuramos obter informações sobre os professores, identificando aqueles que tivessem abertura para fazer conosco a parceria necessária para a pesquisa, ou seja, ter a possibilidade de expor e discutir sobre as opções que fazem em sua ação docente a partir do aluno em sala de aula. Foram designados três professores, e tivemos a oportunidade de estar com eles e com os demais logo no primeiro encontro do Horário de Trabalho Pedagógico Coletivo (HTPC), reunião semanal realizada com todos os professores da escola. Nesse encontro, expusemos aos professores os objetivos da pesquisa, e depois, em particular, solicitamos a colaboração dos indicados. Dois deles, um de primeira e outro de quarta série, se dispuseram a participar, mas, depois das primeiras visitas em suas salas de aula, optamos por nos ater aos alunos de quarta série, uma vez que com eles os diálogos sobre a aprendizagem seriam possibilitados por uma verbalização mais fácil. Além disso, a motivação da professora foi um diferencial importante. 
A estratégia era, no transcurso das atividades, questionar os alunos na medida em que eles as elaboravam,

forma encontrada para fazê-los verbalizar o que poderia ser o seu pensamento, ao mesmo tempo em que seria possível perceber os seus recursos subjetivos e a sua emocionalidade.
Com esse encaminhamento, passamos a freqüentar a sala de aula daquela 4 a série de ensino fundamental, com alunos entre $9 \mathrm{e}$ 12 anos, duas vezes por semana, o que nos permitiu acompanhar as atividades, perceber o comportamento e as realizações dos alunos e observar e conversar continuamente com a professora. Quando possível e oportuno, foram feitas gravações em áudio e vídeo. Também, de comum acordo e em momentos combinados com a professora, pedimos aos alunos a realização de duas atividades: uma redação sobre o tema $O$ que eu quero aprender na escola e um instrumento de complementação de frases, com quarenta e dois itens. Essas atividades também nos deram subsídio para selecionar seis alunos para um outro momento de aprofundamento da pesquisa. Os critérios dessa seleção foram constatações de que o aluno conseguia verbalizar suas experiências, apesar de estar em situação de defasagem escolar. Com os alunos selecionados, foi formado um grupo, com o objetivo de colocar em foco a singularidade de cada um através do diálogo e das expressões espontâneas e complexas que as situações de relacionamento criam, pois a atuação da professora com a turma toda não facilitaria a ocorrência de situações que levassem a desvendar processos subjetivos.

Com esse grupo, em momento específico planejado, foram desenvolvidos dois outros procedimentos da pesquisa, um deles conduzido e planejado pela professora da turma, que implicou uma atividade que pedia a organização de um texto pelos alunos, cujas partes estavam embaralhadas e apareciam escritas em tiras de papel. Eles deveriam colar essas partes e compor uma história coerente. O outro procedimento foi desenvolvido sob o comando da pesquisadora. Essa segunda proposta surgiu em decorrência da primeira, quando não conseguimos captar com clareza, apenas pela fala da professora, quais seriam os significados e sentidos produzidos pelos alunos. Assim, organizamos e desenvolvemos, com o mesmo grupo de alunos, três pequenas tarefas, cada uma em uma folha de papel, que implicavam o uso e a combinação de informações e dicas para a solução de uma dada situação-problema.

Esses dois últimos procedimentos da pesquisa, ou seja, o desenvolvimento das atividades pelos alunos sob os comandos da professora e da pesquisadora permitiu uma troca interessante, quando ambas confrontaram os indicadores que ajudavam a identificar as formas como os alunos utilizavam as informações e dicas para elaborarem as atividades propostas. A estratégia era, no transcurso das atividades, questionar os alunos na medida em que eles as elaboravam, forma encontrada para fazê-los verbalizar o que poderia ser o seu pensamento, ao mesmo tempo em que seria possível perceber os seus recursos subjetivos e a sua emocionalidade. Essa estratégia foi muito interessante e permitiu captar informações importantes que levavam aos indicadores da produção de sentido subjetivo nas tarefas realizadas. Com essa formulação, durante a pesquisa, a professora assumia também o papel de pesquisadora, o que lhe permitiu, segundo seu depoimento, estar em uma outra condição e posição para a compreensão da aprendizagem dos alunos e, em conseqüência, também da sua ação pedagógica.

O que a pesquisa possibilitou, em termos de compreensão dos processos de aprender, na confluência da subjetividade e da produção de sentidos subjetivos, pode ser relatado a partir da apresentação dos casos de dois alunos, pois eles nos dão a oportunidade de compreender as formas bastante singulares pelas quais a aprendizagem se realiza. 


\section{A produção de sentido subjetivo de Leandro e Renan}

Ao serem convidados para participar da pesquisa de forma especial, os alunos sentiram-se orgulhosos e agitados, mas também curiosos e apreensivos, pois existia a conotação de que algo errado poderia estar por trás de um convite daquele. No entanto, a pesquisadora, a quem eles já chamavam também de professora, Ihes era familiar, e já haviam estabelecido com ela alguma relação afetiva.

Durante nossa presença na sala de aula, acompanhando o desenvolvimento de algumas atividades, o aluno Leandro já havia chamado a nossa atenção, pois sua história de escolarização revelava muitas rupturas devido às muitas mudanças de escola já feitas. Ele estava sempre quieto, atento aos movimentos da professora, e mostrava sempre certa apreensão. Tinha alguma defasagem na expressão escrita, pois escrevia cometendo vários erros de ortografia e pontuação, mas era capaz de compor um texto com coerência, o que também foi constatado na redação que elaborou. O seu maior problema, no que se constituía sua maior ansiedade, era a matemática, e, por isso, recebia bastante atenção da professora. $\mathrm{Na}$ sua composição sobre o aprender na escola, destaca que quer "aprender bastante matemática, conta de dividi e de vezes", e que "minha professora, ela tá me ensinando matemática", e também a matemática é seu foco quando completa a frase: "Eu queria saber...matemática; esforço-me...para aprender matemática". Leandro mostra-se tenso e inseguro, o que está presente na forma como ele se relaciona com a professora. Isso pôde ser identificado em determinado momento em que ela pergunta se ele quer ir ao quadro para resolver uma conta de dividir. Ele aceita, vai ao quadro, mas fica inicialmente parado, no que poderíamos supor que estivesse pensando. Logo em seguida, coloca os números errados como resultado da operação, parecendo agir de forma aleatória. No interesse de acompanhar a situação, nós nos aproximamos e nos posicionamos ao seu lado com postura de incentivo.

A professora começa a dialogar com ele e instiga-o a refletir, visando a que ele encontrasse o caminho que poderia conduzilo à realização bem sucedida da atividade. Leandro titubeia, fala sempre baixo, olha para baixo, procura apoiar-se nas orientações da professora, mas sua atividade é sempre insegura, pois, ao dar uma resposta, necessita da confirmação da professora e aguarda que ela o conduza. Assim, com muita ajuda, ele consegue chegar a bom termo na atividade. Quando termina, como estávamos ao lado, seguramos sua mão para parabenizá-lo, e constatamos que ele está suando e tem a mão completamente fria. Isso nos mostrou que o aluno esteve em situação de desafio constante, com uma emocionalidade tensa que pouco poderia ajudá-lo na realização da tarefa. Em outras oportunidades, também nos acercamos dele enquanto realizava tarefas de sala de aula e percebemos que ele parecia estar sempre perdido, parado, não sabendo conduzir a atividade. Sua postura corporal e seu olhar pareciam esperar um comentário ou uma ajuda. Na sua redação, ele comenta, referindo-se à pesquisadora: "A tia que vem aqui quase todos os dias, ela vem ver se meu trabalho tá organizado ou não". Isso mostra que ele se coloca em uma situação de quem está sempre esperando ser avaliado. Dessa forma, ele parecia pedir ajuda, mas, na medida em que a recebia, preocupava-se em esconder isso de alguma forma, pois olhava para os lados para ver se alguém estava acompanhando a situação.

Quando a professora se acercava dele ao perceber que ele estava "travado", mesmo naquele momento só deles, ele parecia 
envergonhado. A estratégia pedagógica usada por ela era incitá-lo por meio de perguntas, de modo que suas próprias respostas the sustentassem o pensamento. Com isso, ele, de fato, mostrava refletir, e acabava conseguindo chegar ao final da tarefa. Sua emocionalidade sempre se mostrava alterada, e ele completa uma frase assim: Não suporto...errar alguma coisa; meu fracasso... foi total, o que é um indicador de sentido subjetivo associado às atividades em sala de aula, em que se misturam medo, insegurança e expectativa de fracasso. Isso vem na direção dos indicadores definidos antes em relação ao desenvolvimento das tarefas, por exemplo, mãos frias e necessidade de que a professora o conduza, o que dá uma idéia da dimensão de sua preocupação com os resultados daquilo que realiza.

Pelas atividades observadas, pudemos interpretar que Leandro ainda não tinha alcançado a autonomia de pensamento, não conduzindo as atividades na combinação das informações dadas para gerar respostas coerentes. A partir de sua insegurança, ele dependia muito do outro para refletir, ou seja, para colocar seu pensamento na conjuntura da situação de forma clara e chegar à finalização da tarefa com sucesso, mas, ao mesmo tempo, parecia não querer chamar a atenção da professora.

$\mathrm{Na}$ atividade que desenvolvemos com o pequeno grupo de alunos, demos uma especial atenção a ele, e o que constatamos foi, da mesma forma, um modo de pensar pouco articulado, que necessitava sempre de muita ajuda, como se lhe faltassem recursos para administrar a situação de aprendizagem. Com ele, era importante o jogo de perguntas para descobrir o que obstruía o seu pensamento. Assim, em uma atividade de organização de palavras dadas para chegar à formação de uma determinada frase, depois de receber a folha e as explicações do que deveria realizar, Leandro ficou quieto no seu lugar, parecendo estar concentrado na solução da atividade. Ele olhava para a folha, registrava algo nela, mas percebia-se que não avançava, pois escrevia e apagava. No entanto, não fazia perguntas e evitava olhar para a pesquisadora, parecendo não querer denunciar-se. Ao chegarmos perto dele, constatamos que havia feito uma tentativa, mas que o resultado era um agrupamento de palavras que não fazia sentido. Nesse momento, então, registrou-se o diálogo da criança (L) com a pesquisadora $(\mathrm{P})$ :

P - "E aí, Leandro, como você fez?"

Ele leu o que havia escrito e, na tentativa de apoiar seu pensamento, a pesquisadora pede:

P - "Leia as palavras que aparecem aqui".

Ele lê as palavras na ordem em que aparecem:

L - "Inverno, iniciasse (a palavra é inicia-se, e a pesquisadora corrige para inicia-se. Ele repete e continua) o, no, mês, de, junho". P - "E agora, o que você acha? Como você forma uma frase com essas palavras? Não precisa escrever, só falar".

A criança diz:

$L$ - "Junho inicia-se no mês de inverno".

P - "Você acha que está bom assim? Tem sentido, assim?"

L - "Não, não tem não, acho que não".

Leandro então parece buscar uma outra alternativa, mas repete a mesma frase:

$\mathrm{L}$ - "Junho inicia-se no mês de inverno".

A pesquisadora insiste:

P - "Você não acha que poderia iniciar a frase com outra palavra? Observe bem, veja se não tem outro jeito".

Ele troca a posição da primeira com a última palavra, e então diz a frase, gaguejando na palavra inicia-se:

$\mathrm{L}$ - "O inverno inicia...a ...sse..... inicia-se no mês de junho".

A pesquisadora faz ar de aprovação, mas, desconfiada, pergunta:

P - "Você sabe o que é inicia-se?" 
Deforma surpreendente para a pesquisadora, ele responde:

L - "Não".

P - "Você não sabe o que é iniciar?"

L - "Ah! É começar!"

$\mathrm{P}$ - "E você sabe o que é inverno?"

$\mathrm{L}$ - "É quando faz frio".

$P$ - "Ah, então faz sentido dizer que o inverno inicia-se no mês de junho?"

L - "Anham!"

P - "Então escreve a frase que você formou agora".

Mesmo ainda ficando dúvidas quanto ao significado que Leandro deu à frase, o diálogo permite apreender o impacto da ausência de um conceito no pensamento da criança. Para a pesquisadora, a leitura clara e pausada e o fornecimento imediato da pronúncia correta da palavra "inicia-se" seria o suficiente para que a organização de uma frase que tivesse sentido aparecesse sem problema. No entanto, Leandro seguiu fazendo tentativas aleatórias e, na investigação da pesquisadora, houve a constatação, com surpresa, de que a não compreensão do significado de uma palavra essencial do texto - inicia-se - era um obstáculo para que pudesse chegar a bom termo na atividade. Tal constatação apareceu de forma imprevista no contexto do diálogo estabelecido com ele. A pergunta que fica é: por que Leandro não perguntou? Por que ele seguiu levando adiante uma atividade que não entendia? Por que seus colegas, quando estavam em situação semelhante, por não saberem o significado de palavras como jangada e lava, que apareciam em outra frase, logo perguntaram à pesquisadora? Por que Leandro parecia querer passar desapercebido e mostrava-se tão tímido e esquivo nos relacionamentos sociais?

É curioso o fato de que, na realidade, o significado da palavra the era conhecido, pois ele mesmo expressou, sem a ajuda do pesquisador, que iniciar significava começar. Portanto, ao que parece, eram as emoções de medo, insegurança e tensão frente à situação que pareciam estar bloqueando a sua possibilidade de refletir e de se ligar intelectualmente à tarefa. Muito provavelmente, a própria relação com o pesquisador era fonte de tensão, o que não Ihe permitia organizar seus recursos para elaborar o que lhe havia sido pedido.

Pudemos constatar nele, também em outras situações, uma tendência a realizar logo uma tarefa sem questionar ou pedir esclarecimentos, e, muito claramente, uma preocupação com a sua posição entre os colegas. Cogitamos, ainda, de que haveria uma produção de sentido subjetivo em relação aos colegas, dos quais se isolava e parecia ter vergonha quando se via recebendo uma atenção particular da professora. Percebia-se uma demonstração de felicidade quando recebia uma aprovação, o que dava a entender que estar em posição de sucesso era bastante valoroso. Essa situação ficou evidente no seu semblante alegre quando, em uma situação fora de sala de aula, ele comentou em voz alta: "Professora, eu já aprendi aquilo que eu não sabia naquele dia do quadro". A aprovação social parecia ser um alvo para Leandro, o que vinha associado a uma emocionalidade que indicava medo e pouca confiança em si mesmo e o conduzia a um movimento constante de autoproteção. Ele mostrava querer esconder o seu não saber, querer sair da situação de menor valor, mas, nas relações da sala de aula, no investimento constante da professora nele, sabia que todos estavam a par da sua situação desvantajosa. Isso evidencia as inter-relações e interdependências entre subjetividade individual e subjetividade social.

Essa análise da necessidade de sair de uma posição de menor valor foi realçada em um fato relatado pela professora, no qual, 
Para a professora, que não está envolvida em fazer uma leitura do fato como uma produção de sentido subjetivo do aluno frente ao erro, o aluno precisaria ser confrontado para assumir o erro, entender o que não sabe, para que pudesse, nessa conscientização, conduzir a si próprio em sua aprendizagem. de forma surpreendentemente segura, ele discutiu com ela sobre um erro que dizia não ter cometido e que ela rebateu de forma radical, provando a ele que havia o erro que ele não queria assumir. Para a professora, que não está envolvida em fazer uma leitura do fato como uma produção de sentido subjetivo do aluno frente ao erro, o aluno precisaria ser confrontado para assumir o erro, entender o que não sabe, para que pudesse, nessa conscientização, conduzir a si próprio em sua aprendizagem. Essa posição, que mostrava ser bastante produtiva, pois apresentava resultados positivos em outras situações, ficou clara em uma dinâmica conversacional conosco, na qual ficou retratada a sua percepção da criança e suas opções pedagógicas. Ela mostrou-se segura ao dizer que não adiantaria ter pena do menino, pois com isso ele não iria aprender. Assim, o que ela precisava fazer era promover a sua reflexão para que ele aprendesse naquele momento, pois cada momento era momento de refletir e aprender, e não existiria outra chance.

Nossa atenção estava sempre voltada para buscar indicadores que poderiam nos fornecer não uma resposta, mas um quadro explicativo para a questão: o que poderia estar atrapalhando Leandro?

Para a professora, havia um significado especial na tentativa do menino de evitar o erro ou de não assumi-lo. Para ela, poderia ser feita uma relação do seu comportamento escolar com o comportamento familiar de acobertamento da realidade. Sua análise estava baseada em alguns fatos e, dentre eles, principalmente, a morte de um irmão de Leandro. Essa perda, que ela informa ter sido um suicídio, teve grande impacto na família, e não era abertamente comentada. Além disso, ou junto a isso, havia uma situação de constante mudança de domicílio residencial, o que não era explicado, e que, segundo sua percepção, não permitia que Leandro tivesse uma escolarização regular em uma mesma instituição. Isso também iria acontecer no semestre seguinte, pois o pai já havia informado a saída da criança da escola. Assim, para a professora, a situação familiar de Leandro era confusa, e ele, naquele momento, morava com a avó, em meio a uma situação encoberta que incluía essa mobilidade de lugares de residência e envolvia a circunstância de uma tragédia. Ainda havia o fato de o pai, militar, viver vestido à paisana por medo de represália de criminosos. A mãe era enfermeira, e era ela quem trocava constantemente de local de trabalho, o que gerava a mudança domiciliar da família. Nessa conjuntura, naquele momento, a mãe estava apartada do filho.

Esse era um contexto social e familiar que envolvia Leandro em uma situação de aprendizagem com muitos percalços, não se sabendo também que tipo de explicações recebia para toda a movimentação familiar. Nosso objetivo não foi fazer a análise de um caso clínico, mas compreender como a aprendizagem de Leandro estava impregnada da produção de sentido daquilo que acontecia em sua volta e como a subjetividade social compunha o quadro da sua aprendizagem. Compreender isso possibilitaria ajudá-lo, pois poderiam ser evidenciadas as formas de ele dar significado aos momentos em que aprendia, podendo ser evitadas aquelas situações de constrangimento nas quais suas defasagensficavamevidentes, principalmente em matemática. No entanto, a professora não estava alerta para compreender essa conjuntura, e, mesmo estranhando e se inquietando com a situação familiar e a grande mobilidade da criança, para ela isso não explicava e não poderia justificar o seu não aprender, no que até podemos concordar com ela.

O que fica claro é que o impacto da situação vivida por Leandro parecia forte, o que pôde ser analisado principalmente pelo conteúdo da atividade de completamento de frases. Dos quarenta e dois itens desse instrumento, 
em dezoito deles, ele completa as frases incluindo situações relacionadas coma família e com o sentimento de perda, evidenciando suas ansiedades, medos e incertezas. Em oito deles, fala do irmão que morreu, o que evidencia essa análise interpretativa: O maior problema... é que meu irmão morreu; eu gostaria...que meu irmão tivesse comigo; fico triste...quando lembro do meu irmão; sinto...muita saudade do meu irmão.

Meu maior medo...é que eu tenho medo de perder meus pais; sofro...quando perco alguém; minha preocupação...é de minha mãe morrer; eu não quero...perder meus pais; fico feliz...quando minha família fica feliz.

O que procuramos compreender é que a subjetividade de Leandro está configurada no confronto de uma subjetividade social de insegurança familiar, cujos padrões de ação parecem não ser o de enfrentamento direto das situações, o que acaba também se apresentando em Leandro. Possivelmente isso crie para ele a dificuldade de olhar objetivamente os dados de uma situação, o que faz com que tudo o confunda, tornando-se necessário que alguém assuma a direção. Leandro parece bastante perdido na maneira como deve olhar os fatos objetivos e pensar a partir deles, pois suas experiências estão inseridas em relações de falseamento, o que pode estar além da situação da morte do irmão, ou seja, há uma historicidade nas relações familiares. Isso aparece também nas situações escolares quando ele se perde na análise objetiva das informações para combiná-las e chegar à solução de problemas e atividades escolares. A partir da conjuntura escolar, familiar e pessoal, angustia-se no enfrentamento das situações de pressão e de conflito como as que a professora e a escola the colocam, sendo-lhe também difícil defrontar-se com suas defasagens escolares, pois não sabe como assumir isso. Podemos entender ainda que, na sua confusão, ao mesmo tempo em que ele se perde no embate de pensar reflexivamente, instalam-se defasagens na conjuntura de aprendizagens não realizadas que se acumulam, o que configura uma subjetividade com baixa autovalorização, que aparece impactando suas relações sociais. Quanto a isso, a professora revela que ele está sempre sozinho, e, às vezes, parece não se sentir parte da turma, e que ela teve que se empenhar bastante para que ele aprendesse a trabalhar em grupo e assumisse também a responsabilidade pelos colegas. Assim, Leandro estava em situação de administrar sua posição no grupo e enfrentar a professora, pois ela não desistia dele, mesmo que ele se sentisse acuado, se protegendo e, muitas vezes, sozinho.

$\mathrm{Na}$ interpretação da professora, Leandro se encobre num jogo de faz-de-conta, vale-se das mudanças constantes de escola para não assumir a responsabilidade de aprender, o que lhe é conveniente, pois torna-se sua desculpa. Com isso, para ela, ele trabalha contra si mesmo, pois, se assumisse a importância de aprender, isso o beneficiaria em qualquer escola que estivesse. Destacamos que a maneira clara de a professora não dar trégua ao aluno, fazendo-o enfrentar suas defasagens, forma que ela acredita ser eficiente para reverter o quadro de sua aprendizagem deficitária, cria possibilidades de ele dar um salto qualitativo, tanto em sua segurança e necessidade de sentir-se competente como, inclusive, nos seus relacionamentos sociais na escola. Pensamos, no entanto, que se ela entendesse o aluno no contexto de sua configuração subjetiva e de sua produção de sentidos subjetivos, poderia abrir outros espaços de intervenção para o aluno no processo de aprendizagem. Isso seria possibilitado mediante a leitura de outros indicadores, na busca da compreensão da forma como nele se articulam os aspectos individuais e sociais. Por isso, a nosso ver, a professora exige dele uma atitude de conscientização 
que Ihe seria difícil executar a partir da própria condição que um pensar reflexivo sobre si mesmo exige. Ainda, a partir do jogo familiar de acobertamento instalado, ele provavelmente tenha aprendido a se comportar dessa forma, evidenciandose esses processos na configuração de sua subjetividade. Essas análises certamente a ajudariam na sua constante tentativa de quebrar posturas cristalizadas nos alunos que, para ela, estão na base da forma como eles se posicionam para aprender. As atitudes cristalizadas que se constituem em condições impeditivas precisam ser quebradas, segundo ela, pois, se não houver essas mudanças, o aprendizado não vai acontecer.

Pudemos identificar, assim, que a aprendizagem de Leandro estava se constituindo na processualidade de forças subjetivas individuais e sociais. Essa trama incluía a sua ação enquanto sujeito concreto no contexto dos vários espaços sociais de sua vivência, ou seja, a conjuntura familiar, o grupo da sala de aula e da escola e a professora, que the impunha desafios constantes e não admitia desistências. Sua aprendizagem estava, portanto, marcada pelo movimento e pelas interligações da subjetividade individual e social.

Um outro aluno que estava sempre em evidência na sala de aula era Renan, que se juntou a esse grupo de 4⿳亠丷a série no ano 2006, depois de problemas de comportamento e disciplina em anos anteriores, com outros professores, na mesma escola. A professora diz ter assumido esse novo desafio a partir de um pedido da direção. De fato, a direção confia no seu trabalho, dizendo que ela consegue fazer com que alunos com defasagem avancem no processo de aprendizagem. A professora reúne em seu currículo experiências bem sucedidas, tendo atuado em turmas de ensino especial, quando essas turmas eram oferecidas na escola. Ela diz procurar alternar as turmas com as quais trabalha em relação ao fato de serem mais ou menos trabalhosas, e que já esteve à frente de muitas turmas consideradas difíceis. No entanto, ela não gosta de ter essa imagem de professora de alunos difíceis, pois já percebeu que os alunos ficam desconfiados por serem problemas, por estarem em sua turma. Na verdade, a professora tem um perfil de muita seriedade e uma crença de sustentação em sua ação que é a de que todo mundo aprende. Assim, ela assume a responsabilidade e torna-se desafiadora do aluno. Ela entende que o aluno aprende sozinho, o que interpretamos na perspectiva de que o comando da aprendizagem deva estar com ele, e que sua atuação está em fazê-lo refletir. Para isso, seu desafio é quebrar as resistências, ou seja, como já identificado, quebrar padrões de comportamento que estejam atuando de forma negativa no processo, impedindo o aluno de refletir. Assim, ela está convencida de que, se conseguir fazer o aluno pensar, ele aprende. Seu objetivo em relação aos seus alunos, principalmente àqueles que estão com defasagem, é investir neles, forçandoos, colocando-os em situação de confronto. Assim, de forma rigorosa, e, às vezes, até ríspida, desafiava o aluno e não deixava que ele esmorecesse ou apresentasse desculpas para atividades, tarefas ou deveres de casa não realizados. Também pedia aos pais atuação e acompanhamento dos filhos, pois esse apoio poderia fazer diferença significativa. Era com essa postura que se envolvia com Renan e estava trabalhando com ele.

Ao contrário de Leandro, que se encobria, Renan queria sempre aparecer. Sua atitude era sempre participativa, gostava de dar sua opinião em tudo, mas nem sempre suas contribuições eram aproveitadas, pois eram pouco objetivas em relação ao tema discutido. Ele tinha muitas informações de assuntos fora da escola, as quais, segundo a 
Podemos, com muita probabilidade de acerto, afirmar que, se Leandro tinha vergonha do seu não saber, Renan também parecia ter, mas enquanto um se calava, se encobria, o outro procurava distanciar-se da situação incomodativa, ou seja, do mesmo sentimento de incompetência, mostrando-se naquilo em que podia receber a atenção do grupo ao provocá-lo, no que geralmente era bem sucedido. professora, eram fruto de horas passadas na frente da televisão, quando via programas variados, mas muitos deles inadequados para a sua idade. Com muitas informações, quase sempre se posicionava como expert em várias temáticas da sala de aula, pois dava palpite em tudo, evidenciando, porém, uma atitude intelectual mais reprodutiva do que elaborativa. Ele repetia o que via, tinha boa articulação de linguagem, gesticulava bastante, entusiasmava-se e parecia considerar que isso fosse suficiente; pelo menos nisso, sentia-se confiante. No entanto, a defasagem em alguns conteúdos escolares, entre eles os de matemática e raciocínio lógico, o estava atrapalhando, pois não conseguia ser bem-sucedido em várias atividades, o que, muito claramente, o levava à dispersão, à desistência, quando apelava para as brincadeiras e as gracinhas, que eram interpretadas como problemas de disciplina. Podemos, com muita probabilidade de acerto, afirmar que, se Leandro tinha vergonha do seu não saber, Renan também parecia ter, mas enquanto um se calava, se encobria, o outro procurava distanciar-se da situação incomodativa, ou seja, do mesmo sentimento de incompetência, mostrandose naquilo em que podia receber a atenção do grupo ao provocá-lo, no que geralmente era bem sucedido.

Foi algo bem próximo disso que se passou em uma atividade proposta pela pesquisadora, cujo objetivo era identificar o fio condutor do pensamento das crianças e a produção de sentidos subjetivos na aprendizagem. Em uma tarefa proposta, pedia-se que fosse descoberto, entre quatro cofres de um banco, desenhados em uma folha de papel, qual era aquele que guardava barras de ouro. Cada cofre era identificado com um número com três algarismos, e, a partir de quatro dicas ou pistas, era possibilitada a análise; em conseqüência, podia-se encontrar o cofre que guardava o ouro. A situação de aprendizagem inicia-se com a apresentação da atividade ao pequeno grupo de crianças selecionadas. Como sempre, já no início da tarefa, Renan ficou inquieto, esquivou-se e mostrou claramente que não se interessava em acompanhar a discussão do grupo. Sua movimentação, por não encontrar a posição certa da mesa e da cadeira, levava o grupo à dispersão. Além disso, ele foi à carteira dos colegas, puxou seus lápis e fez menção de tomar as borrachas, sempre falando alto, no que recebia a reclamação de todos. A pesquisadora, buscando captar seu envolvimento na tarefa, procurou travar com ele um diálogo, na busca de chamá-lo à concentração e poder acompanhar seu pensamento:

P - “Ok, Renan, para você descobrir em que cofre está o ouro, tem que usar as dicas. Olhe! A primeira dica diz que "o algarismo 5 não aparece no número" do cofre com o ouro. E aí ? O que você faz com essa informação?"

Diante da pergunta, Renan olha para o desenho dos quatro cofres, cada um com seu número estampado, e não diz nada. Observa o que se passa com os colegas e não responde. Diz qualquer número, sem fazer qualquer análise. A pesquisadora interfere novamente:

P - "Qual o cofre que tem no seu número o algarismo 5?"

Ele aponta o cofre identificado com o número 195, e a pesquisadora pergunta:

R - "Pode ser esse o cofre com o ouro?"

Ele mostra ficar perdido na análise da possibilidade, e, ao mesmo tempo, outra criança explica que não pode ser aquele cofre, porque nele está o numeral 5. Renan mostra, pelo olhar disperso, que não fez a relação. $A$ pesquisadora orienta as crianças para fazerem um x sobre o cofre 195, excluindo-o entre os possíveis, e Renan faz isso de forma mecânica. A pesquisadora solicita a Renan que leia a segunda pista, e ele o faz:

$\mathrm{R}$ - "O algarismo 6 não aparece na ordem das dezenas". 
O grupo fica quieto, realizando a análise da informação, e logo uma criança expõe sua conclusão de que não pode ser o cofre $\mathrm{n}$ 은 963, que tem o numeral 6 na ordem das dezenas, e segue-se no grupo a exploração sobre os outros algarismos que apareciam na ordem das dezenas, nos outros cofres. Renan observa os cofres e, de repente diz:

\section{R - "Ah! Entendi! Eu entendi!"}

Ele não adianta outro comentário, e, sorrindo, olha para os colegas. A terceira dica é lida por outro aluno, e, de repente, ele novamente diz:

\section{R - "Ah! Eu entendi! É o contrário!"}

A pesquisadora, naquele momento, consegue identificar que as dicas que continham uma negação (não aparece o número...) e a situação de que ele deveria primeiro encontrar o cofre que não era, para poder chegar naquele que interessava, era um obstáculo para o pensamento de Renan. Quando ele percebeu que deveria seguir a idéia de exclusão e pensar a partir de uma negação, pôde acompanhar os colegas. Então, sentiu-se confiante, exibindo um ar de êxito. Se, no início, ele se apresentava disperso, quando entrou na discussão e acompanhou a conclusão dos colegas, conseguiu encontrar o caminho que as dicas apontavam, e nisso apoiou seu pensamento. Assim, a última dica, que dizia "o algarismo 3 aparece na ordem das centenas" (frase afirmativa, o que era mais fácil), logo permitiu que ele apontasse para o cofre 398, que era, então, o que continha as barras de ouro. $\mathrm{O}$ fato de chegar ao final de uma atividade mostrando compreensão pôde ser identificado como uma raridade no seu comportamento em sala de aula. Renan, na maioria das vezes, desistia antes mesmo de tentar, indo um pouco mais adiante apenas se recebesse uma atenção especial da professora. Destaca-se, nas situações observadas, a configuração de uma subjetividade dependente, insegura, mas também ansiosa para receber aprovação social.

Nas observações da sala de aula e em outras atividades com o mesmo pequeno grupo selecionado, ele tendia a se colocar visivelmente na situação de resistência quando a situação o forçava a agir, pensando reflexivamente. De um lado, ele se esquivava, dispersando-se com outra atividade ou agitando-se desnecessariamente, e, se instigado por perguntas, quase sempre dava respostas aleatórias e distanciava-se de uma elaboração que envolvesse a análise de elementos dados para alcançar a resposta de um problema. Ele não se dispunha a explicar porque havia dado uma resposta a determinado problema, porque concluiu ser esta ou aquela a resposta certa da atividade. Como anteriormente descrito, uma resposta que significasse identificar uma relação, ou seja, fazer a combinação entre duas informações, tornava-se um grande desafio para ele. Ainda como exemplo, não the aparecia de forma imediata a resposta sobre qual o número que é maior que cinco e menor que sete, ou como encontrar o algarismo que fosse par e, ao mesmo tempo, menor que três, ou então, qual a palavra começada com $v$ que significava um vento forte. Nessa situação, ele dava qualquer resposta sem analisar detidamente a situação, mostrando-se ansioso para dar por cumprida a tarefa. Para sair da situação de desafio, na inquietação e na não disposição para pensar, buscava um subterfúgio eficaz, ou seja, conseguir as respostas necessárias por outros meios, o que podia significar copiálas ou dos colegas ou do canto da folha da atividade, por ter rapidamente descoberto que elas se encontravam ali escritas em posição invertida. Uma vez que tinha a resposta, parecia considerar ter cumprido a tarefa, não havendo nenhum problema na forma como a conseguia, no que parecia um ar de esperteza. 
A professora percebia esse movimento de Renan e se posicionava, dizendo: "Ele não sabe e não admite que não sabe. Faz um jogo de que não precisa aprender, porque já sabe tudo. Ele fala de tudo e até com certa arrogância, mas aquilo que ele precisa saber para avançar na escola, ele não sabe e ele precisa admitir que não sabe para poder aprender, mas não..." A professora, assim, tinha noção de que precisava "quebrar" essa atitude, para que ele se dispusesse a pensar e a aprender. Ela afirmava que ele era inteligente, mas que armava contra si próprio, naquela atitude de faz-de-conta. Ela o enfrentava, dizendo claramente que ele não sabia, pois, até aquele momento, na escola, só tinha brincado, e que ela não iria deixá-lo continuar assim. Ficava claro que ela estava disposta a mudar essa atitude. De fato, observamos, na sala de aula e no pequeno grupo, que ela se posicionava ao seu lado, fazendo perguntas e exigindo dele as respostas pelas quais dava continuidade à realização da atividade e fazia avançar sua aprendizagem, tal como também aconteceu com a pesquisadora na situação anteriormente exemplificada.

Assim, percebemos que, até aquele momento, ele havia sido avaliado por seus professores apenas como indisciplinado, e que não havia sido identificada essa sua forma de funcionar psicologicamente, ou seja, uma configuração subjetiva na qual procurava atalhos para a solução de problemas, ignorava os desafios e evitava enfrentar aquilo que não sabia. Ele parecia alcançar satisfação em um tipo de saber que apenas absorvia, valorizava e nele se mantinha preso, querendo valer-se disso nas suas relações sociais, pois era o que parecia dar-lhe destaque social.

Procurando indicadores da configuração subjetiva de Renan, encontramos também, nas outras atividades da pesquisa, conteúdos subjetivos que mostravam o desafio que era para Renan vencer certos obstáculos.
Ele afirmou, por exemplo, na atividade de completamento de frases: Eu queria ... saber andar de skate; não posso...andar de skate porque eu caio; o meu maior problema... é não saber, às vezes, as contas; meu fracasso...foi andar quando eu nasci. Meu maior medo...é do escuro; sofro quando... tenho medo do escuro. Essas frases nos ajudam a considerar que Renan percebe aquilo de que não é capaz, e possui um sentimento de insegurança que perpassa várias situações de sua vida dentro e fora da escola. Nessa sua emocionalidade, ele parece ter na mãe um sentido subjetivo de proteção que o faz lembrar-se dela em sete itens do completamento de frases cujo significado revela o medo de estar sozinho:

Minha preocupação... é quando minha mãe está trabalhando; eu sempre posso...ficar com a minha mãe; meu maior prazer... é ver minha mãe ao meu lado. Ainda, o bemestar da mãe se relaciona diretamente com o seu próprio bem-estar: Fico triste...quando minha mãe fica triste; eu não quero...ver minha mãe triste.

Possivelmente exista na família de Renan uma situação de conflito, o que precisaria ser melhor pesquisado e identificado, e dois indicadores nos conduzem a essa hipótese. Um é o fato de Renan em nenhuma frase ter se referido ao pai, em contraposição às várias outras em relação à mãe. Outro indicador é sua afirmação: Não suporto... quando meus pais brigam. Associa-se a isso também a sua referência em relação à tristeza da mãe, já identificada acima. Na frase - Quando tenho dúvidas ... falo com a professora ou com minha mãe, ele pode estar se referindo a dúvidas escolares, mas nota-se que também não busca o pai em situações complicadoras, podendo haver um distanciamento entre eles. Assim, um conflito familiar o faz aproximar-se da mãe e distanciar-se do pai, o que já explicaria ângulos de sua configuração subjetiva, que o fazem afastar-se da realidade que lhe traz 
Minha preocupação... é quando

minha mãe está trabalhando; eu sempre posso...

ficar com a minha mãe; meu maior prazer... é ver minha mãe ao meu lado. Ainda,

o bem-estar da mãe se relaciona diretamente com o seu próprio bem-estar: Fico triste... quando minha mãe fica triste; eu não quero...ver minha mãe triste. sofrimento e aproximar-se do que lhe traz alento. Outro indicador dos seus conflitos é a referência marcante ao medo do escuro, que apareceu em uma das frases associado ao sofrimento, o que tem uma conotação emocional muito forte. No entanto, toda essa dimensão subjetiva das atitudes ou do mau comportamento de Renan passa inadvertida para a escola e seus professores.

A postura displicente que aparece frente às situações desafiadoras envolvidas com sua aprendizagem pode ganhar uma luz explicativa, na qual ele evita o que lhe é desafiador para ficar com o que the dá a certeza do acolhimento. Obviamente, prefere aparecer entre os colegas com aquilo que se convenceu de que sabe, como alguém com alguma competência, do que como alguém a quem faltam saberes e aprendizagens, pois, na subjetividade social da sala de aula, o não saber e o erro são sempre vistos com desconfiança. As crianças e a professora constituem o cenário social da sala de aula, no qual a solidariedade e a cooperação aparecem como participantes, mas também aparece com força o ideal de ser bem-sucedido, o que é constatado pelos resultados e atitudes escolares como: fazer sempre o dever, ter boas notas, acolher as regras e normas instituídas para a boa convivência ou ser disciplinado e respeitoso, estar em dia com as obrigações de estudante, não receber críticas e repreensões da professora. Em contrapartida, acaba aparecendo a necessidade de ser lembrado, elogiado, de estar em posição de destaque, e, caso isso não possa acontecer dentro das regras instituídas, como no caso de Renan, vale consegui-lo por comportamentos de confronto, dando vazão à necessidade de ser reconhecido, o que também carrega a força de sua insegurança pessoal. Nessas análises interpretativas, ficam fundidas as subjetividades individual e social, campo no qual procuramos mostrar a configuração processual da subjetividade de Renan.
Das atividades importantes para Renan, podemos destacar um esporte - o futebol - e ele se refere a isso em cinco itens do completamento de frases dizendo: Eu gosto... de futebol; eu gostaria... de ser jogador de futebol; meu futuro... é ser jogador de futebol. Essa atividade, no entanto, ainda não traz para ele os louros sonhados, e nem mesmo é uma habilidade pela qual recebe a deferência dos colegas, o que certamente Ihe traz grande insatisfação.

Renan mostra também ter consciência das cobranças que lhe são feitas quanto à sua atitude escolar, sabendo reproduzir todo o discurso que parece ter ouvido nos seus anos de estudante. É isso que mostra sua redação sobre $\mathrm{O}$ que eu quero aprender na escola, na qual afirma, dentro do politicamente correto: "Eu quero aprender melhor as contas, ser mais estudioso, fazer mais a lição, aprender a ter mais respeito pelos colegas, pelos professores... Eu quero ficar mais comportado, não ficar falando quando a professora está falando, e não falar na hora de aula". Isso nos mostra um pouco do contexto de sua aprendizagem, da subjetividade social e nos fala da sua história de escolarização e da trama na qual ele se envolveu quando procurou segurança nas relações sociais do ambiente escolar, tomando um caminho (indisciplina e displicência) que o fez acumular defasagens e cristalizar uma postura de defesa e falseamento da realidade, elementos presentes na sua subjetividade e ancoradouros dos seus processos de aprendizagem.

A busca de indicadores para propor uma análise interpretativa de Leandro e Renan nos fez procurar compreender a sua configuração subjetiva, mas, para isso, tivemos que buscar, com a ajuda da professora, desvendar as tramas da subjetividade social e individual nas quais eles se encontram envolvidos, tanto na escola como fora dela.

Com isso, reafirmamos que a aprendizagem acontece na historicidade, na emocionalidade e nos processos simbólicos que integram a 
subjetividade individual e social. Podemos, então, confirmaraidéia dequeaaprendizagem não é simplesmente uma atividade que todos realizam ao longo da vida, mas ou, pois que é realização de um sujeito, uma função sua, e acontece no âmago da produção de sentido continuamente articulada como uma configuração subjetiva singularizada.

\section{Considerações finais}

Nos trechos de informação analisados em relação aos casos apresentados, pode-se deduzir a importância dos sentidos subjetivos que emergem nas atividades dos alunos nas escolas. Em ambos os casos, aparecem sentidos subjetivos nas atividades escolares, configurados não apenas pelas experiências em sala e com a professora, mas na vida social da criança, o que é inseparável da condição subjetiva, a partir do que são assumidos ou enfrentados os desafios trazidos pela escola. Pelo fato de ignorarem a dimensão de sentido subjetivo do desenvolvimento humano, os professores não consideram esses aspectos em suas estratégias de trabalho em sala de aula, o que não thes permite ações diferenciadas orientadas ao apoio à criança para poder superar os problemas subjetivos que afetam sua aprendizagem e seus processos de socialização.

O diálogo na relação de professores e alunos apresenta-se como o canal pelo qual pode transitar a investigação dos processos de aprendizagem dos alunos.

É interessante constatar como os professores consideram a sala de aula apenas em termos instrumentais relacionados ao ensino, e não como um espaço de comunicação e de atividades conjuntas que muito podem ajudar as crianças no seu desenvolvimento subjetivo. Sem o envolvimento da criança e sem a possibilidade de que elas desenvolvam sentidos subjetivos que estejam associados ao prazer de aprender e de estar na escola, os sentidos subjetivos geradores de medo, apatia, insegurança, menor valia e dificuldades de relacionamento social vão ser dominantes em muitas crianças. Sem dúvida, isso pode impedir o desenvolvimento da aprendizagem, como aparece nos resultados apresentados.

Seria desejável incorporar os conhecimentos sobre os aspectos subjetivos da aprendizagem e do desenvolvimento nos programas de formação de professores bem como alertá-los para o aproveitamento do espaço relacional em sala de aula como contexto altamente envolvido com o ensinar e o aprender. São precisamente os sistemas de relacionamento no interior da sala de aula os que permitem o desenvolvimento dos recursos subjetivos das crianças.

Fica evidente que a aprendizagem é uma função do sujeito e que ela se encontra fortemente impactada pelos entrelaçamentos da subjetividade individual e social, em que aparece a diversidade dos sentidos subjetivos como eclosão das singularidades de alunos e professores. 


\section{Maria Carmen Villela Rosa Tacca}

Doutora em Psicologia pela Universidade de Brasília (UNB).

E-mail:mctacca@yahoo.com.br

\section{Fernando Luis González Rey}

Doutor em Psicologia pelo Instituto de Psicologia Geral e Pedagógica de Moscou; Docente do Centro Universitário de Brasília (UniCEUB).

E-mail: gonzalezrey@terra.com.br

Endereço para correspondência:

SQS 311, Bloco H, ap. 604 Cep: 70364-080, Brasília-DF

Recebido 18/04/07 Reformulado 02/10/07 Aprovado 19/11/07

Ariès. (1978). História social da família e da criança. Rio de Janeiro: RTC Editora.

Campos, G. R. A. (2005). A constituição subjetiva de alunos em situação de fracasso escolar. Dissertação de Mestrado em Educação, Universidade de Brasília, Brasília, DF.

Cardinalli, C. (2006). Uma análise da configuração subjetiva do aluno com dificuldades na aprendizagem. Dissertaç̃o de Mestrado em Psicologia, Pontifícia Universidade Católica de Campinas, Campinas, SP.

Gomes, C. (2005). Sentidos subjetivos de alunos portadores de necessidades especiais acerca da inclusão escolar. Dissertação de Mestrado em Psicologia, Pontifícia Universidade Católica de Campinas, Campinas, SP.

Gonzalez Rey, F. L. (1996). Problemas epistemológicos de la psicología. La Habana, Cuba: Editorial Académica.

Gonzalez Rey, F. L. (1997). Epistemología cualitativa y subjetividad. La Habana, Cuba: Editorial Pueblo y Educación, Playa.

Gonzalez Rey, F. L. (2000). La categoría sentido y su significación en la construcción del pensamiento psicológico. Contrapontos, Itajai, 1(2), 13-28.

Gonzalez Rey, F. L. (2002). Sujeto y subjetividad: una aproximación histórico-cultural. México, DF: Editora Thomson

Gonzalez Rey, F. L. (2003). Sujeito e subjetividade. São Paulo: Pioneira Thomson Learning.

Gonzalez Rey, F. L. (2004). O social na psicologia e a psicologia social: a emergência do sujeito. Petrópolis, RJ: Vozes.

Gonzalez Rey, F. L. (2006). O sujeito que aprende: desafios do desenvolvimento do tema da aprendizagem na psicologia e na prática pedagógica. In M. C. V. R. Tacça, Aprendizagem e trabalho pedagógico. Campinas, SP: Ed. Átomo e Alínea.
Morin, E. (1999). O conhecimento do conhecimento. Porto Alegre: Sulina.

Patto, M. H. S. (1990). A produção do fracasso na escola. São Paulo: T.A. Queiroz Editores.

Pinheiro, P. M. A. (2004). Sucesso escolar: uma possibilidade na relação professor-aluno. Dissertação de Mestrado em Educação, Universidade de Brasília, Brasília, DF.

Tacca, M. C. V. R. (1999, julho/dezembro). Professores, suas crenças e as possibilidades de sucesso de seus alunos. Revista Linhas Críticas, Brasília, 5(9).

Tacca, M. C. V. R. (2004). Nem professor, nem aluno: a alteridade nos processos de ensinar e aprender. In L. Simões \& A. Mitjans Martìnez, O outro no desenvolvimento humano. São Paulo: Thonsom.

Tacca, M. C. V. R. (2006a). Relações sociais na escola e desenvolvimento da subjetividade. In M. I. Maluf et al. Aprendizagem: tramas do conhecimento, do saber e da subjetividade. Petrópolis, RJ: Vozes.

Tacca, M. C. V. R. (2006b). Estratégias pedagógicas: conceituações e desdobramentos com o foco na relação professor-aluno. In M. C. V. R. Tacca, Aprendizagem e trabalho pedagógico. Campinas, SP: Ed. Átomo e Alínea.

Tunes, E., \& Bartholo, R. S. (2006). O trabalho pedagógico na escola inclusiva. In M. C. V. R Tacca, Aprendizagem e trabalho pedagógico. Campinas, SP: Ed. Átomo e Alínea.

Tunes, E., Tacca, M. C. V. R. \& Mitjáns Martinez, A. (2006, janeiro/junho). Psicologia e educação: sobre aprendizagem e escola. Revista Linhas Críticas, Brasília, 2(22).

Vygotski, L. S. (1997). Fundamentos da defectología. In Obras escogidas (Tomo 5). Madrid: Visor. (Trabalho original publicado em 1935) 